\title{
Mission Command: An Exploration of its Issues in Multinational Units
}

\section{RENÉ OCHS}

\begin{abstract}
This paper explores the application of mission command in binational and multinational units within the NATO context. It explores differences in understanding and application of mission command, amongst NATO members, and identifies the negative impact that these can have on the behaviour of tactical leaders, and on mission accomplishment, within a multinational context. The paper demonstrates that the understanding and therefore the application of mission command differs between the NATO members; that this influences the leadership style of superiors and their willingness to transfer trust and responsibility, and to assume risk; and, that differences in language, understanding and meaning of terms, and different contents of intents result in a negative influence, all of which are exacerbated by political influence. On the other hand, modern technology in binational or multinational units supports and promotes the application of mission command. The paper concludes with recommendations to mitigate these problems and to create the conditions where mission command can be employed successfully.
\end{abstract}

Since its foundation, the North Atlantic Treaty Organization (NATO) has been striving to collaborate. This corporate ambition has become more important since the end of the Cold War and the beginning of the out-of-area deployments (NATO, Topics, 2017). A necessary prerequisite for cooperation in NATO is interoperability, the ability of military forces to operate in conjunction with each other (Freudenberg, 2005). NATO defines interoperability as "the ability to act together coherently, effectively and efficiently to achieve Allied tactical, operational and strategic objectives" (NATO, 2013, p. 2-I-8). Within this context it "allows forces, units and systems to operate together" (NATO, 2006, p. 3). One of the imperative needs for this cooperation among different multinational units is a common command and control (C2) concept.

During the first decades of the Cold War NATO planned its defence against an attack from the Warsaw Pact with the "layered cake approach" with "national corps after national corps standing shoulder to shoulder" (Ciocan, 2011, pp. 53-54). Interoperability was only required at the boundaries or in the case of the deployment of a reserve force. Within this defence concept of single fighting nations, a common C2 concept was therefore not an issue. 
In the 1970s and 1980s the coalition recognised that this approach "was an inadequate counter to current Soviet doctrine" (Bungay, 2003, p. 10). It followed that a new manoeuvreoriented approach which allowed more flexibility and initiative at all levels of command was required (Freudenberg, 2009). As a prerequisite for the implementation of this approach, NATO land forces started to introduce the German C2 concept of mission command (Shamir, 2010). It derived from the knowledge that "the battle would be too fast ... mission command would be vital” (Freudenberg, 2009, p. 65).

Recently with the end of the Cold War, and missions in operational theatres worldwide, there has been a shift within NATO from previous national military operations to operations where multinational units down to platoon level are working together (Ciocan, 2011, p. 54). With this shift, a common C2 concept down to the lowest tactical level became more relevant (Wallander, 2000).

A quick review of the doctrine for land forces of the 29 NATO members reveals that the vast majority prefer to utilise mission command (see for example Kommando Heer. 2017; Department of the Army, 2012; Land Warfare Development Centre, 2017; Ministerie van Defensie, 2012; Department of National Defence, 2009). From this viewpoint it seems that mission command is an interoperable $\mathrm{C} 2$ concept for mission accomplishment within NATO land forces. But is this the reality? Has, for example, a Dutch, a French, a Norwegian or a U.S. Company Commander the same understanding of mission command as their German Battle Group Commander? Or are there issues with the application of this determined C2 concept in multinational units?

The aim of this article is to critical examine the contemporary application of mission command in binational and multinational units within NATO. This is based on the German tenets of mission command. This exploration will focus at the lowest tactical level, from a German perspective a combat forces battalion.

\section{PART ONE. Literature Review}

\section{Mission Command}

For a successful framing of this analysis it is important to define the term mission command. Existing literature uses in an interchangeable manner for mission command the terms "mission orders", "mission-type tactics", "directive control" (Bühlmann \& Braun, 2010) or "mission-type order" (Speller, 2017). NATO defines it as an "order issued to a subordinate unit that indicates the mission to be accomplished without specifying how it is to be done" (NATO, 2013, p. 2-M-9).

Shamir (2010, p. 245) describes mission command more precisely as "decentralized leadership", as "a philosophy of command that requires and facilitates initiative of command directly involved with events on the battlefield." Dunivan (2003, p. 2) agrees when he states, it "empowers subordinate leaders to exercise during the battle. To exploit opportunities and subordinates' initiative, the commander should explain the mission and intent, then allow subordinates the freedom to figure out how to accomplish the mission." These authors provide a generally accepted understanding of mission command, which has been developed over time. 
Mission command has its foundation in the German concept of Auftragstaktik. This concept dates back to 14 October 1806 when two Prussian Armies were decisively defeated and psychologically devastated by the French Army at the twin battles of Jena and Auerstedt, although the Prussians were numerically equal in Jena and markedly superior in Auerstedt (Oetting, 1993).

The reasons for this defeat can be summarised as follows. On one side, the Prussian Army had established a centralised C2 system, "nobody took action without order to do so" (Bungay, 2003, p. 1). Shamir (2011, p. 29) assesses that this was as a result of the Newtonian scientific approach which argued that the "objective reality can be controlled", and that warfighting and command in war could be applied with mathematical tools which would deliver universal rules and formulae. This approach ended in a tightly limited mind-set of Prussian officers, paired with rigid inflexible tactics, so that opportunities could not be exploited during the battle (Shamir, 2011).

Napoleon divided the French La Grande Armeé in Corps as a combined arms formation with sufficient infantry, cavalry, artillery, engineers, service units and a C2 headquarters to operate independently for several days (Britt, 2003, p.33), and fought with flexible combat tactics within this Corps-system and a common basic tactical doctrine. In contrast to the Prussians, Napoleon "delegate[d] authority to the independent Corps" (Shamir, 2011, p. 32). This degree of decentralisation promoted the tactical flexibility of the Corps, which allowed for Napoleons' stated aim, that subordinates should use their initiative and act without orders in accordance with his intentions (Bungay, 2003, p. 2). Shamir (2011) considers that this 'Napoleonian' system enabled quick decision-making and was the basis for the astonishing success.

This defeat and the analysis that followed by the Prussian military reformers Lieutenant General von Scharnhorst, Field Marshal von Gneisenau and later Major General Carl von Clausewitz highlighted that "the nature of war requires quick decisions and flexible plans" as "warfare is governed by the unknown and unforeseen. Hence, an invariable gap develops between planning and actual events" (Shamir, 2011, pp. 33-34). Von Scharnhorst determined, war has no scientific rules, only "correct concepts that are grounded in the nature of things and experience" (Shamir, 2011, p. 33). Consequently, it is "the best way to prepare an officer for the demands of the battlefield to teach him these correct concepts and then encourage him to think and make independent analysis and decisions" (Shamir, 2011, p. 33) to close these gaps.

The result was an acceptance that military leaders at the lower tactical level must have more responsibility, must think independently and possess personal initiative (Bühlmann \& Braun, 2010). This approach, known as Auftragstaktik, was institutionalised in the Prussian Army by Field Marshal Helmuth von Moltke the Elder. He recognised that a military leader on the battlefield "must judge the situation for themselves and must know how to act independently in consonance with the general intention" (Hughes, 1993, p. 131), then "no plan of operations extends with any certainty beyond the first contact with the main hostile force. ... The advantage of the situation will never be fully utilised if subordinate commanders 
waits for orders.... It will be generally more advisable to protect actively and keep the initiative ..." (Hughes, 1993, pp. 92 \& 132-133).

This decentralised C2 concept was embedded in the Prussian Army. It was implemented in the Army regulations and in training and education of military leaders to conquer the Clausewitzian uncertainty and the "fog of war" (Leistenschneider, 2009; Oetting, 1993). Bungay (2003) states, that it is important for military success that each level understands the intention of the higher command to fulfil its objective; "senior commanders should not order more than is absolutely necessary but should ensure that the goal was clear. In case of doubt, subordinate commanders should seize the initiative" (Bungay, 2003, p. 3). This top-down and bottom-up C2 concept was successfully adapted into the German military culture and is the current $\mathrm{C} 2$ concept of the Bundeswehr.

\section{Mission Command Today}

The concept of Auftragstaktik is the uppermost C2 principle of the German Army (Kommando Heer, 2017). In harmony with the understanding of NATO (2016, p. 2-5) it is based on the principle of centralised planning and advocates decentralised execution to be able to meet with uncertainty in any dynamic and complex environment.

In terms of von Moltke, it requires that a military superior formulates and informs subordinates about his intention and the mission objective, which defines the starting point for all activities of the subordinate leaders. The superior gives unambiguous and attainable objectives which are to be achieved by the subordinates and provides the necessary forces, means, time and information to accomplish the mission. Constraints and restrictions are only imposed to bring actions and effects of other actors who serve for the same mission objective into harmony. With this, subordinates can develop initiative and creativity within the given limitations. This form of command stresses the "What" without prescribing the "How" (Kommando Heer, 2017).

Freudenberg (2009) refers to this application as a functional approach. It leads to "rapid decision-making on an uncertain battlefield ... to seizing opportunity without hesitation" (Dunivan, 2003, p. 4). This implies consistent training and education to enable unity in thought and action of military leaders at all levels. The significant number of successes attributed to this $\mathrm{C} 2$ concept led to its adoption by NATO and at a national level by a number of nations, in particular the U.S. and the British Army.

International definitions of mission command appear consistently similar (see for example Department of National Defence, 2009, p. 5-2; Department of the Army, 2012, pp. 11 to 1-2; Irish Defence Forces, 2016, pp. 8-5 to 8-7; Land Warfare Development Centre, 2017, p. 6-4, Ministerie van Defensie, 2012, p. 36). In contrast to that deduction stands the result of a survey from Stewart, Cremin, Mills, \& Phipps from 2004 about the use of mission command in multinational units. "People sign up and say we do mission command when they don't at all, and some of the nations in the coalition will have actually been brought up to the exact antithesis of mission command, ..." (Stewart et al, 2004, pp. 5-6). This points to issues with the application of mission command within multinational units. Other authors support this viewpoint (see for example Leonhard, 1991; Macey, 1998; Millotat, 2002; Alwyn-Foster, 2005; Shamir, 2010). 


\section{Issues with Mission Command}

During the Cold War, NATO planned its defence against a possible Soviet attack with national units standing side by side (Ciocan, 2011). A common C2 concept was not an issue. Today with the current NATO missions there has been a shift to operations where multinational units down to platoon level are working together (Ciocan, 2011). With this shift issues of $C 2$ became more relevant (Wallander, 2000).

Few authors have dealt directly with the issue of mission command in combined units. However, a significant body of research does exist that addresses multinational deployments and the implied issues with soldiers from different nations, and some of these deal with mission command in peacekeeping operations. From the available literature the issues with the application of mission command in multinational units can be summarised under the following headings: different understanding of mission command and with that; different styles of leadership; language problems; effects of modern technology; and political influences.

\section{Understanding of Mission Command}

Nations interpret and implement mission command into their culture in different ways. Culture is "the values, norms and assumptions that guide human action" (Wilson, 2008, p. 14). Ruffa $(2012$, p. 188) defines the specific military culture form as "...a core set of beliefs, attitudes and values that become deeply embedded within the military unit and guide the way it manages its internal and external life, the way it interprets its tactical and operational objectives and the way it learns and adapts." This is embedded through the historical development of its military forces and is founded in its structure and organisation, its procedures and hence in its $\mathrm{C} 2$ behaviour.

Elron, Shamir and Ben-Ari (1999) examined multinational units and the influence of different military cultures on how they work and operate. They found that "in cultures characterised by high uncertainty avoidance there may be a greater demand for detailed plans and orders than in countries characterized by higher tolerance for uncertainty" (Elron et al, 1999, p. 80). Mission command "was the German response ... to the unavoidable friction and fog inherent to the phenomena of war" (Shamir, 2011, p. 52). The military culture in other NATO nations has developed differently on account of their history. In contrast to the Germans, Anglo-American forces have followed a managerial approach.

For the U.S. forces Shamir (2011, p. 62) describes it as an industrial approach which "was influenced by Frederick Taylor's principles of scientific management. They sought to control war through efficient planning and execution processes". As a result of this approach a mechanised and centralised C2 concept was established, with quantitative mathematical methods and models to assess the effectiveness. This concept was institutionalised "through top-down control, endless regulations and inspections focused on inputs rather than outcomes" (Vandergriff, 2013, p. 5). The aim was to minimise this uncertainty. It enforced the military culture, the training methods and the $\mathrm{C} 2$ behaviour of the U.S. Forces and was encouraged through the high industrial capabilities and the use of modern technology.

In the British Army this centralised C2 concept was also applied. Shamir (2011, p. 67) found that this was a result of its island situation and its "isolation" from the European continent. Traditionally the military culture favoured the Navy over the Army. The Field Army was spread in small garrisons as result of its imperial role, fighting small wars and skirmishes 
and did not often participate in wars and conflicts in Europe. Therefore, it was not influenced by the military C2 developments on the European continent. Freudenberg $(2009$, p. 64) notes additionally that $\mathrm{C} 2$ in the British Army was framed on the objective of "[m]ilitary effectiveness ... from platoon to the highest level". This objective, the traditional regimental system and the understanding of officers led to the application of centralised C2.

As result of these historical developments Anglo-American forces and most of the NATO nations prefered a C2 concept which had centralised decision-making, with schematic and explicit orders and plans from above, and a strict obedience by subordinates, requiring limited decision-making and initiative on their part. This C2 concept was "business management rather than the Moltkean style of command" (Shamir, 2011, p. 65). It was taught through all levels of command and ranks.

Since the 1970s and 1980s in reaction to Soviet superiority, NATO and especially AngloAmerican land forces started to introduce mission command as a new command concept (Shamir, 2010, p. 653). Watters $(2013$, p. 2) describes it as "[a] move from the large set piece orchestral military 'symphony' to 'jazz', that is extemporisation on a theme, the theme was commander's intent and the permission to extemporise was embodied Mission Command". In spite of its ordered adoption, mission command is not fully integrated.

For the U.S. Army Shamir (2010, p. 666) has determined, that "fundamental organization policies and training methods have not sufficiently changed". Guthrie (2012, p. 26) underlines this with his note that "the centralized planning headquarters establishes three back briefs and seven in-process reviews before the decentralized executors are approved". Häberli (2010) summarises his experiences at lower tactical levels when he indicates that during training, mission command is strongly promoted, but it evolves in the reality of a complex battlefield to the application of detailed orders.

Macey (1998) describes the same effect for the British Army; the training does not reflect mission command as the defined C2 concept: "Middle-piece officers" have no idea and experiences of what mission command means and what causes it. He sought to explain this with the "top-heavy, unresponsive, bureaucratic procedures" which has less to do with a "flexible, decentralised structure that can respond swiftly to the need of the moment" (Macey, 1998 , pp. 87-88). Watters (2013, p. 2) confirms this by stating: "The shift from the comfort of certainty ingrained over years through the rehearsal of set piece battles on a repetitive cycle of annual exercises ... to uncertainty and extemporisation was an uncomfortable wind of change for many ... warriors".

Millotat (2002, p. 27) believes that mission command in NATO and most of their members "is only a lip-service". Under the pressure of time and with complicated tasks, he further explains, Allied military leaders revert to those command concepts with which they are familiar: centralised decision-making and detailed orders for execution. This refers to different styles of military leadership.

\section{Leadership}

Spacie (2000, p. 86) describes leadership as the position of people or a group influencing others within a given context, and this influencing is necessary for the direction of effort in every activity. Shamir (2011, p. 49) determines that leadership within mission command requires training and education for "... NCOs and officers to command one or two levels above 
their rank" because "every situation in a battle or war is unique and ... appropriate maneuvers ... could not be pre-planned in meticulous detail" (Spacie, 2000, p. 23). Thus, as Keithly and Perris (1999, p. 129) describe, a "uniformity in the way of thinking, sound judgement and initiative" is achievable.

For this decentralised execution to take place, two prerequisites are indispensable. Schmidtchen (2001, p. 11) and Watters (2013, pp. 3-5) summarise these as two principles of mission command: "Trust" and "Risk". Mutual trust contends on one hand, that superiors have the confidence that subordinates will execute the mission within the commander's stated intention and that superiors give only tasks which are achievable. On the other hand, this includes also the clear understanding of subordinates to act in accordance with this intention and to make prompt decisions "that will achieve the intention despite changing circumstances ... based on minimal and sometimes conflicting information" (Schmidtchen, 2001, p. 12).

The acceptance of risk is the other principle which requires the responsibility for conducting an operation passes to the subordinate. With that, subordinates have the independence to fulfil the task. Thus, there is a degree of risk in the achievement and "[s]uperior commanders must accept that where there is risk, errors will be made" (Schmidtchen, 2001, p. 12). To achieve this "thinking leader" it requires a functioning superiorsubordinate relationship.

Leadership is dependent on the manner in which $\mathrm{C} 2$ is conducted. An examination of the official doctrine, as outlined previously, indicates that this style of leadership should be the common leadership style within NATO. It should follow Patton's maxim: "Never tell people how to do things. Tell them what to do and they will surprise you with their ingenuity" (Patton, 2017). However, research shows that this is not the case. Shamir $(2011$, p. 21$)$ indicates that in Anglo-American forces leadership is "expressed through strong control procedures." Pryer (2013, p. 35) further explains that subordinates are encouraged to "do things by book. [A]II contain rubrics explaining how to solve a specific problem. If a trainee misses a step or finds another solution, retraining is required". Vandergriff $(2013$, p. 1$)$ underpins this with his statement that in spite of ordered mission command, "senior commanders ... micro-manage their subordinates".

In the same way Macey (1998, p. 89) notes that "a lack of confidence in subordinates is one of the reasons some commanders are reluctant to implement mission command." From this point of view, different leadership practices result in different understandings of mission command. This has to be seen as another potential issue in this context of multinational units. Rubenstein, Keller and Scherger (2008, p. 544) reinforce this and point to different military cultures and different ways of leadership that "are significant complicating factors to ... interoperability".

Elron et al (1999) mention in addition that different skills and attitudes, different training and doctrine, different superior-subordinate relations or diverse norms can create issues with the application of mission command. These may be reinforced through language barriers.

\section{Language}

Mission command stresses the 'What' without prescribing the 'How'. In a multinational unit or environment mutual understanding is crucial to the success of the mission. Clarity and effective communication between the different nationalities is vital. Stewart et al $(2004$, p. 5) 
identify "language difficulties and differences in the way national contingents interpret information or command intent" as obstacles to mission command.

Biehl (2012) argues that a common language is the prerequisite for a tightened communication structure. NATO has English as a common language which is intended to prevent communicative misunderstandings. Non-Native-English-speaking countries have adopted English in the training of their soldiers, but not sufficiently, according to Biehl (2012, p.135), "the further development of English language skills should be emphasized". Stewart et al (2004, pp. 5-6) argue that "[i]ncompatibility in language has the potential to introduce substantial friction to the multinational force." This is a significant issue for the execution of mission command.

Besides difficulties with the spoken and written language, "[m]ission command requires a certain quality of education and a common language" (Ben-Shalom \& Shamir, 2011, p. 110). Nelson (1987, p. 26) describes this to be "a common outlook on the nature of war", "a common approach in understanding and applying tactical principles" and "precise, standard and widely understood military terminology". For him this "common outlook and language reassured both leaders and subordinates, reinforcing that sense of mutual trust and dependability [that is] ... conducive to initiative and freedom of action". NATO has standardised its military terminology, military symbols and abbreviations to alleviate this issue (NATO, 2013). In contrast to that, Stewart et al (2004, p. 5) ascertain that "the understanding or interpretation of what is being said ... differ from that intended by the person providing the communication".

Language is vital when it comes to interpreting commander's intent. Dempsey \& Chavous (2013, p. 62) explain that commander's intent "succinctly describes what constitutes success. It includes the operation's purpose, key tasks, and the conditions that define the end state". But a review of the literature demonstrates that this is not always the case.

In an examination of Anglo-American forces, Albert and Hayes (1995, pp. 86-87) observed that the U.S. Army tends to use detailed directives which articulate missions and objectives for two levels down of subordinates and offer substantial guidance about how the objectives are to be achieved. This "problem-solving" approach provides more detailed direction and impact on the space for lower level initiative and creativity in accomplishing the objectives negatively. Stewart $(2009$, p. 57) validates this in his research. He states that commander's intent in the U.S. Army comprises "an inappropriately high proportion of planrelated detail". The British Army use the "problem-bounding" approach. It composes the directives in terms of the objectives to be accomplished, but expresses them in very general terms. Stewart $(2009$, p. 57) notes that "details of the plan ... [are] ... relatively low". In comparison, the directives are less detailed than those of the U.S. Army, but more specific than mere assignments and contain some explicit limitations.

In contrast to this extensive approach, the commander's intent in the German Army contains the idea of the operation, outlined in broad terms and phases, the purpose and the desired end state. It follows the Moltkean approach of "only to order that which is absolutely necessary" (Oliviero, 2001, p. 57). This differing interpretation of the content of commander's intent and the resulting ambiguity in the language leads to misunderstanding, as Shattuck \& Woods (2000, p. 11) identified, which "arise when superiors and subordinates do not share a common understanding". This leads to command by detailed orders which can dilute the application of mission command (Stewart, 2009, p. 57). 


\section{Technology}

As early as the 1990s, some militaries and academics expressed their conviction that modern technology would change the adopted way of many armed forces to mission command. Jablonsky (1994) and Bateman (1996) considered that, with modern technology and a digitalised battlefield, the freedom of action of subordinates, a paramount component of mission command, will be heavily reduced, because higher commands have a better situational overview. Mission command "cannot survive on the digital battlefield" (Bateman, 1996, p. 15). Leonhard (1991) argued that it is wrong if a superior does not intervene directly in the events if he is disposed of better information than his subordinate.

It has been argued that modern technology "... will trade mass for tempo. The difference in operating tempo of digitised forces and that of analogue forces will be stark" (Blad \& Potts, 2003, p. 145). Cohen (2004) adds that modern technology ensures that commanders operate in a communication environment which is inherently different from before and that this increases the decision cycle speed. It ensures the availability of all kinds of information and the observation of forces for every command level.

The use of modern technology creates many advantages. Bühlmann \& Braun (2002) believe that it thins out the "Clausewitzian fog of war" and it annuls the friction while obtaining as far as possible certainty. They argue that this technology leads to the minimisation of uncertainty "by bringing back the Commander's Hill" (Bühlmann \& Braun, 2010 , p. 58). But the literature has shown that it also influences the application of mission command.

In an examination of multinational units, Vogelaar \& Kramer (2004) found, that the use of modern technology in an extensive information and communication network permits close supervision of subordinate units. "Superior commander closely monitor his subcommanders", "started to interfere in the decisions of their subcommanders" and thus "close supervision stifles initiative and risk-taking by subcommanders" (Vogelaar \& Kramer, 2004, p. 424). Watters $(2013$, p. 3) affirms this assessment and underlines it with his finding: modern technology "enable[s] micromanagement, or the 'long screwdriver', whilst potentially absolving subordinates from the responsibility of decision-making".

Van Bezooijen \& Kramer (2015, pp. 450-452) support this view when they found that modern technology "made higher-level commanders hesitant to delegate authority to subordinate commanders, leading to centralization of command and micromanagement". While technology accelerates the decision circle through information superiority, it results in a decrease in mutual trust, initiative and risk-taking amongst subordinates. Keithly and Perris $(1999$, p. 5) further identify that the resultant detailed-order command ignores as far as possible the "on-the-spot assessment of the situation, resulting from careful observation and Fingerspitzengefühl (fingertip sense)" limiting the subordinate's opportunity to make correct and appropriate decision. "[T]he cult of technology" leads to the "danger entailed in overreliance on technology at the expense of the human factor" (Kober, 2011, p. 724).

\section{Political Influence}

The literature also identifies political influence on military $\mathrm{C} 2$ as further potential issue for mission command in multinational units. Combined units and deployments are mostly the will and the decision of politicians (Stewart et al, 2004). Operations in a volatile environment require multinational forces which have previously trained together and have established 
appropriate command structures and operational procedures. Without common training and preparation, different understandings of $\mathrm{C} 2$ and therefore different structures, doctrines and styles of leadership can occur which undermine the application of mission command (Blad \& Potts, 2003).

Additionally, the literature presents restrictions and caveats from national governments as another form of political influence. These are frequently expressed in the form of Rules of Engagement (ROE). NATO (2013, p. 2-R-10) defines ROEs as "[d]irectives ... which specify the circumstances and limitations under which forces will initiate and/or continue combat engagement with other forces encountered." ROEs are a political state's guidance to its military forces detailing when, where, how, and why the forces accomplish a mission and against whom force may be used. "They are attempts [by] political leadership to regulate relevant military events in anticipation and contain political, military- strategically, operational and tactical requirements above all national justice bonds" (Freudenberg, 2012, pp. 19-21).

For most authors on the subject the ROEs are an issue for the application of mission command. Potts \& Blad (2003, p. 145) indicate that this issue is "an inevitable consequence when wars are a matter of national choice, and not national survival". They describe that the human costs especially influence the public support of military deployments in multinational units, and thus influences the political leadership which then again influence the military. This is a difficulty in combined units with different nationalities, which are more or less susceptible to changing levels of public support for their actions. In addition to that, other authors observe in the application of restrictive ROEs a direct intervention from political leaders regardless of the chain of command to the lowest military levels. Thus, mission command does not determine the command behaviour but rather the rigorous codes of conduct expressed as ROEs by the political level do (Freudenberg, 2012).

This political behaviour is caused by a number of factors. Storr (2003) attributes it to the time and space aspects of modern information technology, and the availability of information in real time across the globe. Actions of soldiers and forces can be disseminated immediately by the media. "The pressure on the political leadership to act or explain is particularly acute" (Widder, 2002, p. 6). The high political sensitivity results in the requirement to supervise "sensitive activities very closely and also to develop strict rules to guide these actions" (Vogelaar \& Kramer, 2004, p. 426).

Actions at the lowest tactical level can have an operational or even strategic impact (Storr, 2003, p. 123). "Therefore, detailed political guidance is seen as the guarantee to success, with the result that the military has a limited field of action" (Widder, 2002, p. 6).

\section{PART TWO: Methodology}

Part One, above, highlighted the development of mission command, derived from the German C2 concept of Auftragstaktik, and its contemporary understanding and application in the Bundeswehr. Mission command is defined as the current C2 concept within NATO and the forces of most of its member states. There exists a consistency in definition and understanding in respect of mission command across these states. However, there are issues with the application of mission command in multinational units. This is related to different understandings of mission command and resultant different styles of leadership, and further complicated by language barriers, the use of modern technology and political influence. These 
five issues are not conducive to a common application of mission command in a multinational environment.

To examine this in more detail, semi- structured questionnaires of relevant NATO personnel were employed to capture the contemporary and potential issues with the application of mission command in combined units. This research was anchored in the German understanding and application of mission command, but attempted to incorporate the views and experiences from both the 'German' and the 'foreign' perspective. Therefore, the majority of participants were German tactical military leaders with broad military experiences in contemporary overseas deployments and exercises within different binational or multinational units. It was focused on those military units which have recently or are currently participating in binational or multinational formations.

To ensure the perspective from the non-German side, the research included tactical military leaders from these foreign units which are currently part of formations mentioned above. This led to a relatively broad sample of 22 respondents. This broad sample was necessary to ensure that both sides were captured, the German and the 'foreign' side, from platoon to regiment level and above, and they could give their actual impressions and experiences with mission command, due to this experience.

A semi-structured questionnaire was used to gain "rich data" (McGinn, 2018). The intention of this method was on one hand to ensure that the same areas of information were collected. On the other hand, this still allowed a degree of freedom and adaptability in eliciting information from each respondent. The use of standardised, open-ended questions facilitated faster analysis and easier comparison.

The questionnaire was divided into seven sections, commencing with some personal information to record respondents' background as military leaders, so as to correlate this with their experiences with mission command in binational and multinational units. This was followed by five sections of questions about the contemporary or potential issues of mission command derived from the literature review. The final questions gave respondents the opportunity to express any further issues with the application of mission command, which are not mentioned in the literature review. The questionnaire was tested by a pilot to identify flaws, omissions, layout and comprehension.

Taking into consideration that most participants were in Germany, France, The Netherlands or overseas and from different nationalities, the questionnaire were devised in two languages, German and English, which were administered with a focused set of openended questions utilising an online survey format. This method of surveying respondents gave them sufficient time to reflect on their own experiences and to mitigate scheduling conflicts created by a lack of time. To provide sufficient context to these questions and to ensure a baseline understanding of mission command and its application, all respondents were provided with the current German doctrinal understanding and tenets of mission command and a brief historical genesis of its derivation from the German concept of Auftragstaktik.

Based on the content analysis of the initial data set from the online questionnaire, the research attempted to identify common themes of contemporary or potential issues and connect them to the reviewed literature. The responses from the interviewees were coded based on general themes, such as what are the issues with the application of mission command in binational or multinational units and the possible reasons for these issues. The 
responses were also coded based on specific issues the respondents thought were important as contemporary or potential issues for the application of mission command. These individual responses were then categorised into groupings from which five key themes emerged, which are covered in detail below.

\section{PART THREE: Research findings and analysis.}

Part One presented the generally accepted definition and understanding of mission command and its historical development. It outlined the theoretical underpinnings of this functional C2 approach, and showed that there are issues with the application of this C2 philosophy in binational and multinational units within NATO. Five themes were deduced as contemporary or potential issues which shaped the interview questions used in the research.

The first theme is a different understanding of mission command in other nations in comparison to the German understanding. The second theme carries on from the first and is about these differences reflected in the behaviour of military leaders. Additional areas emerging from the literature review were language barriers, technology, and political influence which were identified as issues that can interfere or impede mission command. The purpose here is to analyse the data collected during research focusing on these five themes while examining their significance for the successful application of mission command within combined units. This data was collected from a respondent pool of mostly German and some foreign officers.

The survey process and the data analysis reveal that the emergent themes from the literature review are issues for a successful application of mission command in combined units. In fact, between the NATO nations there exists a dissonance in the understanding of mission command and how it is to be applied. Only on the basis of not yet gained or limited experience among the interviewees, the effects of technology on the application of mission command, suggested in the literature, could not be confirmed. However, all respondents saw its potential for negative effects on mission command.

\section{Understanding of Mission Command}

The first part of the questionnaire was developed with reference to the section about understanding of mission command from the literature review. For a common understanding and for context, all interviewees were provided with the current German definition and understanding of mission command, the definition and understanding of NATO and central members derived from their doctrine, and a brief historical background of this $\mathrm{C} 2$ philosophy. All respondents were asked whether mission command is applied in this sense, are there differences in the understanding of mission command between the nations and which issues and problems occur consequently in binational or multinational units.

All respondents confirmed that in their respective armed forces mission command is adopted within their $\mathrm{C} 2$ doctrine and the definition and understanding of mission command is similar to the German model. They also agreed that from their experiences with armed forces of other NATO nations, mission command is the adopted C2 philosophy. Respondent 1 concludes: "they understand mission command like us".

Emerging from this line of questions was the theme that, despite adopted mission command, the application of this C2 philosophy at the lower tactical level differs from the 
doctrine. Apart from a few exceptions, most of the German and "foreign" respondents affirmed this. Respondent 5 summarised that its "application differs greatly in practice". The majority of the German respondents revealed that mission command is understood and applied in the German sense in those multinational units which are led by Germans or from states "from a similar cultural area..." (Respondent 3). The same cannot be said for other nations. Respondent 22 for example commented that for the U.S. Forces "mission command is suggested outwardly that American soldiers apply mission command, but on closer inspection it is not equal to the German understanding". Respondent 7 went even further and stated that in most nations it is "more a platitude than reality". Respondent 20, a U.S. officer, echoed this, "[t]he U.S. military is really trying to adopt mission command philosophy in the same regard as defined above ... However, it is sometimes difficult to implement given a number of different influences and variables". And Respondent 19, a French officer, commented that the French military has "the same understanding of Auftragstaktik ... Though, the level of expectation could differ". Three reasons for these differences can be derived from the present data.

As first reason the manner of decision-making process is mentioned. Respondent 12 noted that a German superior "takes a less present role in the decision-making process and transfers more responsibility and initiative to his/ her staff during the preparation of the decision". In contrast to that, Respondent 8 stated that in rather Anglo-American influenced armed forces decision-making "is a commander's driven process. [D]ecisions will be seldom prepared through the staff ... The staff is rather there to write orders and provide PowerPointSlides.". As a result, freedom of action, creativity and initiative for staff members to contribute to the decision are restricted. Respondent 21 expressed this as follows: "[s]pecialist expertise, which one tries to introduce in the [decision-making] process in the sense of ... showing initiative and giving advice, is smiled or gazed funnily because this seems unusual".

From the majority of respondents, the level of detail in issued orders was referred to as the second reason for a different application of mission command, which resulted in more or less freedom of action, creativity and initiative in the execution of orders by subordinates. This finding corresponds to the aforementioned differences in the application of mission command in the different nations. Respondent 4 summarised this with "a variance in verbal orders or OPORDs". Respondent 11 stated that in German led multinational units "mission command is strictly applied in orders". The same result can be derived for those nations which are "from a similar cultural area" (Respondent 3). Respondent 22 commented in regard to other nations that "... there is a lot of explicit orders down to the lowest level ... Much odds and ends will be ordered". Respondent 19 supplemented that "planners and order-givers ... explain very precisely the way to achieve the goal, the "how'". As result, "... extensive planning is not necessary ... mostly a co-ordinating function for subordinates remain." (Respondent 21).

These findings underpin Stewart's et al (2004) conclusions from a survey and the assessments of scientific research of Millotat (2002), Häberli (2010), Shamir (2011), Guthrie (2012) and Vandergriff (2013). In spite of its ordered adoption, mission command is not fully integrated and/ or applied within NATO or rather in its members. The responses also suggest that at least in these armed forces the managerial C2 approach is consistently applied. Respondent 13 described it appropriately as "the attempt to calculate and predict the battle and operations as much detail as possible with 'mathematical' tenets to be prepared for all eventualities". 
This suggestion for armed forces of nations "outside the German military cultural area" is underlined through many respondents and their experiences that superiors exercise a high degree of control over their subordinates. "[D]ouble and triple hedges" through "mission analysis brief ... intermediate back brief ... final commander's back brief" (Respondent 17). It led to the perception that for own planning steps the approval of the next higher commander must be caught up" (Respondent 13). This finding bears out the research of Shamir (2010), Guthrie (2012) and Vandergriff (2013).

As a third reason, a significant number of respondents point out that in multinational units many subordinates will be led by, and indeed desire, detailed orders. Respondent 10 entitled this as "wish for ... detailed-order command." Respondent 5 described this even more clearly: "I also found that the Platoon Commanders were happy with the high level of direction they received and seemed to function better when there was no ambiguity relating to either why or how a mission should be achieved." As possible reasons for this, uncertainty as subordinate leader in a multinational environment, a lack of knowledge of superiors and their characteristics, a lack of mutual trust between both, unknown or different techniques and procedures, and language barriers are voiced. These points relate to other themes which will be analysed below.

To summarise, it can be determined, that although a similar definition and understanding of mission command in NATO and most of its member states from a doctrinal perspective exists, the understanding of mission command differs between nations. This leads in binational and multinational units to a higher degree of control and report measures to issues with the application of mission command. Consequently, the advantages of mission command are thereby weakened or dissolved in parts. This can range from "subordinated units which have hived off" (Respondent 12), and thus jeopardise the achievement of commander's intent and the mission objective, to subordinated units which "don't know, what to do" (Respondent 9) without detailed orders.

Unanimously, all respondents considered as a main reason, alongside the different understandings of mission command, a lack of common training and exercises, and common $\mathrm{C} 2$ techniques and procedures within NATO at the lower tactical level.

\section{Leadership}

The second part of the questions related to leadership. All respondents were asked which leadership factors and characteristics promote and prevent the application of mission command, how important mutual trust and the tolerance of mistakes is, and how a different understanding of mission command is reflected in leadership.

All respondents stated in general that military professional competence and personal leadership skills are the necessary prerequisites for the successful application of mission command in a multinational environment. Respondent 13 summarised this as "a very high skill of the military craft, a maximum in military competence and professionalism".

An interesting line of responses came out of reactions to the posited leadership factors and characteristics. Firstly, with overwhelming consensus the respondents saw trust as the most important factor for a successful application of mission command. The description of the importance range from "fundamental" through "the central" and "core factor" to "it is the key" and "crucial for the application of mission command". Respondent 5 stated: "[m] utual 
trust in my opinion is probably one of the most vital factors for the successful application of mission command." Other respondents substantiated this and explained that "trust in the counterpart is the foundation for mission command" (Respondents 11 and 22) and "without this tenet the principle of mission command with the necessary degree of entrepreneurial freedom cannot work" (Respondent 8). Respondent 16 summarised this and pronounced: "Mutual trust is prerequisite for mission command. This trust must be based on military professionalism, loyalty, and in particular a clear understanding of commander's intent."

Along with trust, risk appetite and the tolerance of mistakes was seen by the majority of the respondents as a second important factor which promotes or prevents the application of mission command. Respondent 4 stated that "[m]utual trust and the tolerance of genuine mistakes is a fundamental component of ... mission command. Without this ... mission command cannot be applied". Respondent 19 supported this and noted that "the give-amistake-a-chance is a very powerful concept to better integrate ... mission command". And Respondent 2 elaborated that it supports subordinates "to go unconventional ways, to be creative and to think 'out of the box'".

These responses corroborate clearly the research findings and conclusions of Schmidtchen (2001) and Watters (2013) as highlighted in Part One. The collated data from the survey affirms that trust and the corresponding tolerance of mistakes are indispensable prerequisites for the successful application of mission command. Additionally, these responses suggest that mutual trust and risk appetite are the core, the central elements, to successfully apply mission command. Together they create the required functioning superiorsubordinate relationship which facilitates its application.

From the answers of the respondents to the aforementioned questions, several other factors could be identified which promote or prevent mission command in a multinational environment. Two important themes emerged from the data which are connected to both elements of trust and risk: communication and the behaviour of military leaders.

Many respondents saw communication, and the communication style and ability of superior commanders, as a basic prerequisite to apply mission command in units from different nations. Respondent 5 pointed out:

The better a superior commander can communicate his intent the more comfortable a subordinate commander will be with the ambiguity surrounding the HOW aspect of achieving the mission. Those commanders with a competent communications style will clearly dictate the WHY and therefore empower their subordinates to a higher level.

Respondent 3 made a similar point and highlighted that in combined units "... trust arises only and exclusively through personal contact and communicative interaction among each other". Respondent 21 supplemented this and noted that "... superiors must interact with subordinates professionally as well as humanly ... they must advise and steadily develop [subordinates]. Thus, mutual trust increases." And "[w]ith increasing mutual trust and ... reliability, mission command will be increasingly applied" (Respondent 3 ). This data seems to indicate that on one hand trust and tolerance of risk, and on the other hand communication are concepts and factors which are linked with each other. They create the necessary 
"familiarity" (Respondent 20) between different nations for a successful application of mission command.

Another important factor emerging from the survey responses was the behaviour of military leaders in such units. Many respondents see in the personality of superior commanders a further factor which promotes or prevents mission command. Besides several other character traits, the function as role-model is specially emphasized. "The superior must lead by personal example" noted Respondent 21 . And Respondent 17 outlined:

Superiors have to put mission command into practice day-to-day. Thus, they shape and educate their subordinate commanders and soldiers so that mission command will be promoted. [Without this] ... missing experiences with mission command leads to issues [for subordinates] with its application, especially in stressful situations. As result, the danger increased that subordinates will be led by detailed orders and micro-managed.

These responses are consistent with the research work of Shamir (2011), Pryer (2013) and Vandergriff (2013), who illustrate in their publications the consequences and issues with the application of mission command if this $\mathrm{C} 2$ philosophy is not taught. And this data suggests that a successful application of mission command is linked to the personality and more specifically to the behaviour of the superior commanders.

The findings of this section can be summarised as follows: mutual trust and the tolerance of mistakes between superiors and subordinates are the central factors for the successful application of mission command in a multinational environment. The derived conclusions in Part One were confirmed by the respondents. With communication and behaviour of leaders two further factors emerging from the responses which are deeply connected with mutual trust and risk appetite. Both have a significant influence on the application of mission command and can lead to the same issues described in the section of understanding of mission command in this part, if they are not respected and applied.

The majority of respondents considered that as a result of a lack of time for common training and exercises, the creation of mutual trust between superiors and subordinates from different nations is negatively influenced and therefore the application of mission command in binational and multinational units.

\section{Language}

In the third part of the survey, the respondents were asked about the influence of language on mission command. The responses show that language has a significant impact on the application of mission command in a multinational environment. Generally, most respondents stated that "[b]oth written and spoken military language" (Respondent 4) was "very important" (Respondent 15), "decisive" (Respondent 1) and "essential" (Respondent 16). They confirmed the conclusion from the literature review that language deficits are an issue for the application of mission command. "[As] effects were to be observed that orders were misunderstood and tasks were executed wrong" summarised Respondent 12.

Unexpectedly, two of the respondents have different experiences. Respondent 9 deemed language "as no obstacle for the application of mission command". Respondent 18 elaborated this and explained: "[f]rom my point of view, mission command is separated from 
the language. If the idea and the purpose of mission command is understood, then the language will be no obstacle". Further explanations and reasons for this statement were not given.

As described and outlined above, three themes emerged from this part of the survey which influence mission command in its application within combined units. The first theme is English as common C2 language within NATO. Many responses supported the idea that different language skills in English impact mission command negatively. Respondent 16 states: "[d]ifferent language levels and poor English knowledge lead to command and control problems within multinational units". Respondent 5 further explained that "the Commander more comfortable with English was more willing to issue orders in a manner similar to Mission Command while those with a poorer standard tended to be more exact". "[W]ith the detailed explanation of an order on the basis of linguistic barriers the freedom for the recipient of the order gets lost" underlined Respondent 2.

Interestingly, two respondents had opposite experiences. For Respondent 2 nonnative English speakers were better promoters of mission command; he stated that "nonnative speakers are better to understand then native speakers because they use an easier English." Respondent 22 underlined this 'advantage' and emphasised that:

If the language skills of the different nations are not to $100 \%$ coincide then has mission command a significant advantage in comparison to detailed-order command. ... Detailed-order command requires a much more accurately and more detailed exchange of information and this is difficult if somebody has not the appropriate [English] language skills.

Despite these responses, the emerged data substantiates the research findings of Stewart et al (2004) and Biehl (2012) that different English skills are a contemporary issue in a multinational environment and that this has the potential for substantial frictions.

With regard to the second theme with similar consequences, all respondents affirmed that a common military terminology was important and vital for the successful application of mission command. Respondent 4 stated:

Military language when viewed through the lens of military orders/tasks and Mission Command is critical due to its specificity and definition of terms. ... NOT fully comprehending the intent of a superior or the tasking of a subordinate will result in failure.

All respondents confirmed that the accepted military terminology differs between NATO members, despite a NATO standardisation regulation in this field. Respondent 3 stated that "a common character set is not implemented within all NATO members." Respondent 22 elaborated that this "application of different military terms in connection with different ... meanings behind one term lead to misunderstandings, and therefore to issues with mission command. Different language skills aggravated this..., especially if a term could not be translated one to one in another language". Additionally, some German respondents explained that several "NATO military terms have more than one meaning. This confuses Germans the most. German military terms are more clear and precise" (Respondent 1). 
This finding bears out and corroborates the research of Stewart et al (2004) as outlined in Part One. A key point from all respondents was, derived from its frequency of mention, that only a restrictive implemented and trained application of the common NATO terminology in all member states can solve this issue.

Finally, from the responses emerged a third theme that can be an issue with the application of mission command in combined units: namely commander's intent and the procedure behind it to prepare his or her decision. Most of the respondents noted that in the applied national processes of decision-making differences are ascertainable. Respondent 11 outlined this as follows: "the German process is more results-orientated in comparison to the more process-orientated procedure of the most other nations". This statement corresponds with the explanation about the decision-making process discussed above.

These different orientations and procedures will be reflected in the form and content of commander's intent. The majority of the German and "foreign" respondents noted that there were issues with this application under mission command. For example, Respondent 8, a German officer, described his experiences with the 'U.S. version' of commander's intent: "[i]f you read as a typically trained German officer a US order, then at the beginning you understand nothing. All is significantly repeated several times". Respondent 1 explained this with a "much more comprehensive and more conceptual process ... which ends in a very detailed and extensive commander's intent". In contrast to that, he further explained that other nations "... have the same problems with the brief, bare, precise, clear, and focused German process". "And with the six Ws (Wer, Was, Wie, Wann, Wo, Wozu; translated: Who, What, How, When, Where, Why) of the pure German version of commander's intent" as Respondent 8 adds. Unfortunately, more detailed descriptions of this issue were not made from the "foreign" respondents so that a further correlation could not be carried out.

This finding is similar to the research from Albert \& Hayes (1995) and Stewart (2009) and echoes their contention that different nations prefer different formulations of commander's intent with regard to scope and content. Simultaneously, the research from Shattuck \& Woods (2000) which found that a different understanding in commander's intent leads to misunderstanding and ambiguity in the execution was confirmed. These responses also suggest that in the armed forces of NATO members either the "problem-solving" or the "problem-bounding" approach is applied, according to Albert \& Hayes (1995). However, the depth of responses could not confirm their research results.

In conclusion, all three emergent themes from the data underline the conclusions from Part One. Different English skills and levels, different military terminology or different definitions and meanings of military terms, and differences in the scope and content of commander's intent are and can be a possible issue for the application of mission command. For the majority of the respondents, a better and common language training and education in English, especially a common standardisation of military terms, techniques and procedures, and their strict implementation, training and application within NATO nations, can significantly reduce this issue.

\section{Technology}

In this part, the respondents were asked about the influences which modern technology and information capabilities have on the application of mission command in binational and multinational units. In general, from the generated data it is possible to determine that a 
comprehensive and interoperable deployment of modern technology is, contrary to the conclusion from the literature review, only a partial reality at the lower tactical level in such units. Representative of the responses, Respondent 13 stated "[ $t$ ] he transparent battlefield exists only in the advertisement of the armaments industry".

All respondents affirmed that modern technology and information systems are utilised in their respective armed forces but that these systems are only partially operational, at best. "In the multinational environment I have not experienced such a full interoperable technology" noted Respondent 8 and "the influence on command and control was to be neglected" (Respondent 16). "In many exercises and overseas deployments I have experiences that there are breakages again and again between the different national systems" supplemented Respondent 13. Therefore, the respondents elaborated, they have only limited experiences which the answers reflect.

From the available data, two themes of influence of the application of mission command emerged, a positive and a negative influence which are in line with the reviewed literature. From their experiences, many respondents support the argument that modern technology influences $\mathrm{C} 2$ in a positive way. Respondent 20 stated that "technology gives higher level commanders a better picture and situational awareness" and "... promotes information gathering..." Respondent 2 further explained that this leads to "a comprehensive situational awareness which supports subordinates to get a broader view and to make appropriate decisions."

Respondent 20 strengthened this with his statement:

However, I have realised that while the commander in the operations center does have more situational awareness of things on the ground, technology has yet to replace some of the variables you can only identify and realize on the ground. Likewise, leaders on the ground lack some of the awareness the commanders in the operations center have. They best units I have seen are able to effectively communicate. This means the commander in the operations center uses his increased situational awareness to support the leaders on the ground while still empowering them to make decisions.

These responses refer to the fact that modern technology has a positive influence on the application of mission command. It supports decision-making for subordinates 'on the ground' and does not reduce its advantages. Furthermore, the data indicates that modern technology can thin out the 'fog of war' through obtaining more certainty which confirms the findings by Blad \& Potts (2003), Cohen (2004) and Bühlmann \& Braun (2010) as described in Part One. Additionally to this, Respondent 4 stated:

Constantly improving C4ISR systems will disperse some of the fog of war but in my experiences they can never fully clear it. [N]otwithstanding the expensive capabilities of modern information and communications systems the application of Mission Command is even more important as the operating environment becomes more uncertain and complex. ... Of critical importance is the understanding that Mission Command facilitates all levels of command 
achieving the mission when uncertainties impact upon awareness, Communications and information systems.

Respondent 19 summarised several experiences of other respondents that "[ $t$ ]here will be always a fog of war." This finding is in contrast to the assumptions outlined in the first part about the effects of modern technology on mission command from Leonhard (1991), Jablonsky (1994) and Bateman (1996), and indicates clearly that mission command is more necessary with its use. "Centralised command and decentralised execution are even more important to accomplish the essential task and the mission" as Respondent 17 summarised.

On the other hand, the majority of the respondents estimated that modern technology can have a negative influence on mission command, and thus can be a potential issue for its application. From the data emerged a number of key points which express this negative influence and effects: "Micromanagement and levering of command levels" (Respondent 18); "Leap over of command levels" (Respondent 1); "Disturbance of chain of command" (Respondent 3); "Overstrain control" (Respondent 12); "May lower the necessary trust a commander has to give to [a] subordinate by being able to control/ monitor every move in real-time" (Respondent 19); or "Loss of confidence in the decision-making ability of soldiers on the battlefield" (Respondent 10).

However, all of these statements of the respondents are assumptions and expectations. In the present data, there are no concrete experiences which affirm these responses. Therefore, these responses can only connote that modern technology may have a negative impact on mission command and can be a potential issue for its application. The research findings of Vogelaar \& Kramer (2004), Watters (2013) or Van Bezooijen \& Kramer (2015) from Part One cannot be substantiated. Their findings that technology stifles initiative and risk-taking of subordinates, enables micromanagement, and leads to a centralisation of command and execution, could not be confirmed with this research.

As a conclusion, the data from the questionnaires states clearly that the contemporary use of modern technology in a multinational environment has positive effects on $\mathrm{C} 2$ and improves the application of mission command. The information, gained with it, supports the on-the-spot assessment and decision-making of subordinates. However, "[t]he human 'eye' on the ground still has a crucial role" (Respondent 10). The responses also point out that modern technology can have a negative influence of mission command. Thus, technology is a potential issue for its application in combined units.

\section{Political Influence}

With regard to the reviewed literature, the last questions the respondents were asked related to the role which political influence plays in the application of mission command, and which effects national caveats, restrictions and ROEs have on it in a multinational environment. The responses generated several factors as to how it influences mission command.

In general, the majority of the respondents stated that political influence was not an issue for the application of mission command at their lower tactical level as platoon leader or company commander, or had only a marginal, negligible influence. On the part of the staff officers at battalion/ regiment level, three respondents confirmed that political influence had an impact on mission command. Respondent 16 and 17, both German staff officers in the German-French Brigade, illustrated in summary, that the creation of this binational unit was 
the political will from both nations. However, clear foundations and framework conditions for the common cooperation, which have to arise from the military experts, were and are not fixed through the political decision-makers. In particular, both pointed out that there is no common C2 language, no common decision-making process or other common operational procedures and doctrine. These lead to issues with the application of mission command.

Respondent 4 outlines another experience:

One instance of where I experienced the negative effects of political influence was where ... several officers of various nations declared that they were unable to act on the orders issued. As directed by their relevant domestic political institutions, they were required to request and await permission in order to act to carry out the orders issued. ... [A]s a result the mission was NOT accomplished in a timely and effective manner ...

These responses strengthen the research work of Blad \& Potts (2003) which conclude the same results as mentioned from both German staff officers; and they relate to the key points which evolved in the previous sections.

As regards the question of the influence of national caveats, restrictions and ROEs on mission command, most respondents see these as an issue for the application of mission command. And they substantiate this with their own experiences. For example, Respondent 15 describes his experiences as follows:

Different ROEs, national caveats and so on are of big influence on mission command in multinational units. Each nation has to be aware and familiar with the set of rules which others apply and work by. This influence ... has its effect on how and in what way units can be deployed. This is not only of influence in the pre-planning phase but also, and maybe even of more importance, during the deployment of units in action.

Respondent 13 reported from his experiences and described the behaviour of military leaders from some other nations as "they only act and execute tasks with a written order". Respondent 20 underpinned this:

From my experience it plays a significant role. More restrictive ROE results in decision making being held higher levels which can take away from true mission command. It would fog the decision-making process [to] take away commander's willingness to accept prudent risks. It hinders disciplined initiative as commanders would be less comfortable empower leaders to make unilateral decisions.

These outlined experiences are sound examples and corroborate in a clear manner the research results and key points from Potts \& Blad (2003) and Freudenberg (2012) which conclude from their work that political leadership influences the military in combined units, that caveats, restrictions and especially ROEs intervene directly in the command behaviour and that this greatly influences and restricts mission command. Respondent 19 summarised: 
[T]he highly sensitive context (political, cultural, religious) prevents any [commander] from let too much initiative to the subordinates. As General Krulak explained, the very corporal is strategic and so we have to control every last move he could do to fulfil his mission and then be sure that the completed execution will make the force gain and no pain.

This statement is similar to the key point by Vogelaar \& Kramer (2004) and supports their conclusion that politicians supervise the military very closely and develop strict rules to guide their actions.

In summary, the responses from this part of the questionnaire have demonstrated that political influence and political measures like national caveats, restrictions and ROEs have an enormous influence on the application of mission command and are contemporary issues for its application in binational and multinational forces. Thereby, determining that these issues affect the tactical level down to battalion. Significant influences down to the lower tactical levels cannot be ascertained from the survey.

\section{Summary}

This part presented the pertinent results of the survey process to examine five contemporary or potential issues for the application of mission command in a multinational environment from the previously reviewed literature. These results were analysed and related to each other, as applicable. Several themes emerged from this research in relation to the derived issues.

First, despite similar understandings of mission command and its anchoring in C2 doctrine, the understanding behind mission command differs within NATO and its members, which leads to different applications of this philosophy in combined units. This is especially reflected in Anglo-American armed forces which tend toward a managerial approach of C2 in the direction of detailed-order command. These differences then will be transferred to the leadership style.

Second, mutual trust and the necessary tolerance of mistakes are central elements of a functional relationship between superiors and subordinates from different nations and therefore fundamental for the application of mission command in binational and multinational units. Both must be accompanied by communication to create this relationship and thus to establish trust and risk appetite; and by a suitable behaviour of the superiors who have to demonstrate and enact mission command daily.

Third, different skills and levels of spoken and written English as common C2 language, different military terms which are also ambiguous in their meaning, and different formulations of commander's intent as result of different decision-making processes are an issue in these multi-linguistic units and cause a partial or complete turning away from mission command.

Fourth, the currently available and deployed modern technology and information systems have not had the negative effects on mission command as outlined in the literature review. Quite the converse, they promote and improve its application in a multinational environment. However, potentials to influence mission command in a negative manner will be seen. 
Finally, political influence impedes mission command. "The working under the guidance of ... political heads and the multi-national commander" (Respondent 20) complicates an effective application in combined units. Especially national caveats, restrictions and ROEs as political measures constitute primary drivers which influence the tenets behind this $\mathrm{C} 2$ philosophy massively.

From the data of the survey it is deducible that different understandings of mission command, correspondingly different leadership styles, language barriers, modern technology and political influence are issues for the application of mission command in a multinational environment. These findings confirm the derived issues from the literature reviewed in Part One and are explored in more detail below.

\section{PART FOUR: Conclusions and Recommendations}

This study attempted to critically examine the contemporary application of mission command in binational and multinational units within NATO. Based on the German tenets of this C2 philosophy, the research was focused at the lowest tactical level to determine key themes which have effects on its application in this environment.

Part One explored mission command as the C2 philosophy for "rapid decision-making on an uncertain battlefield ... to seizing opportunity without hesitation" (Dunivan, 2003, p. 4). Five themes emerged from the literature which have an impact on the successful application of mission command in a multinational environment. Related to these themes, five findings are deducible from the primary research:

\section{Finding 1: Mission Command is not the same as Mission Command}

Differences exists in its understanding and application in combined units. As a result, these lead to less freedom of action and initiative given by superiors to subordinates. In addition, with the application of a high degree of control and reporting measures the advantages of mission command were weakened or dissolved in parts.

\section{Finding 2: Leadership style makes the difference}

Mutual trust and risk appetite are the core elements for the successful application of mission command in units consisting of soldiers from different nations. In connection with communication and leadership behaviour they create the climate where mission command can occur. To conduct this required leadership style the same understanding of what mission command means and entails is necessary.

\section{Finding 3: Language hinders}

Despite a common NATO language and standardised military terms, difficulties with the use of English, misunderstood and ambiguous military terms and different contents of commander's intent lead to threats for mission accomplishment and more detailed-order command in binational and multinational units.

\section{Finding 4: Technology improves}

In contrast to the reviewed literature, which anticipated a negative influence, modern technology supports superiors as well as subordinate leaders in their estimate of the situation 
and their decision-making process. Contemporarily, it supplements the 'eyes on the ground' and promotes the application of mission command without replacing Commanders-on-Scene.

\section{Finding 5: Politicians influence}

Up to the lowest tactical levels, the work of military leaders in a multinational environment is complicated by political influence, requiring adherence to two chains of command and different national limitations. These impede the $\mathrm{C} 2$ behaviour and therefore the application of mission command in combined units.

\section{Recommendations}

The findings of the primary research corroborated four of the five issues which were derived from the existing literature on mission command in binational or multinational units. With the exception of modern technology, all other issues have a negative influence or impact on its application. Additionally, from the responses and the examined data several recommendations emerged as possible solutions for these issues and as opportunities to reduce the negative effects on mission command and its application.

Firstly, to mitigate misunderstandings about what mission command is and which tenets lie behind this $\mathrm{C} 2$ philosophy, the overwhelming majority of the respondents proposed that a common NATO definition is necessary. This doctrinal work should serve to explain the tenets underlying this form of $\mathrm{C} 2$, and must be implemented in the regulatory landscape of NATO down to the lowest tactical level. Furthermore, this doctrine has to be strictly adopted and implemented in the national doctrine of the member states, and its application strictly controlled. Only these measures can remedy this deficiency.

Secondly, and founded on the first recommendation, common training and education standards should be created within NATO. Additionally, they should be adopted, implemented and applied in national training and education schemes for officers and NCOs. This is vital to ensuring a common understanding of mission command. Therefore, unity in thought and action can be achieved and with these a successful application in binational and multinational units.

Besides these opportunities, increased frequency of training exercises in a multinational NATO framework is necessary to cement mission command as an interoperable C2 measure in practice. This requires more time, but enhances the creation of mutual trust and risk appetite between superiors and subordinates from different nations at the lowest tactical level. This improves their communication and leadership behaviour as necessary prerequisites for its successful application in a multinational environment.

Finally, the language barrier must be eliminated. This can happen through some effective NATO measures, combined with their adoption and implementation at the national level of its members, and restrictive control measures. Language education in English requires standardisation. This must include a commonly agreed doctrine with defined military terms and symbols, supplemented with clear, precise and unambiguous definitions. In addition, NATO has to standardise its techniques, procedures and processes at the lowest tactical levels. Most importantly, a common NATO decision-making process adopted, implemented and applied within every NATO member with common structures and contents is vital to mitigate misunderstanding and ambiguity. 


\section{Areas for Further Research}

Several areas for further research emerged from the data that were beyond the scope of this study. The presented research work from several academics in Part One shows a comprehensive picture about the adoption, implementation and application of mission command in the U.S. and UK armed forces. Research within other NATO members on the same topic would be interesting courses of study, to explore similarities and differences, and thus to create a basis for improvements for the $\mathrm{C} 2$ interoperability at the lowest tactical levels in this organisation. With the expected increasing digitisation of the battlefield and more use of modern technology, further research about the effects of these on C2 and leadership behaviour would add great value to the discussion about mission command and its application.

Furthermore, German respondents see the way of training and education of officers and NCOs in the German armed forces as critical, positively as well as negatively. The adopted German strategy with the takeover of tactics regulations directly from NATO with corresponding comments should be examined in terms of its contribution to ensure a common C2 interoperability. English language training for officers and NCOs candidates should be explored as to how this prepares future tactical leaders for multinational deployments. Finally, the institutionalised and formalised officer and NCO training and education schemes should be examined as to how they impact on the training and application of mission command. These areas could be theses in themselves. Finally, from the responses it became clear that the question of how to impart mission command at best in a peacetime training environment is a further important research area which has to earn academic attention.

\section{Conclusions}

Capewell (2018) describes the increasingly complex challenges of the 21st century as "volatile and hybrid" and summarises this with shifts in power around the world, different motivated state and non-state actors, and increasing interconnection between military and non-military means in conflicts and wars. The literature consulted and the primary research in the main identified mission command as the most suitable form of C2 to facilitate mastery of these complex challenges.

The research findings state clearly that, despite its adoption in doctrine, the successful application of mission command in binational and multinational units within NATO is not guaranteed. A key finding of the research is that a different understanding of this C2 philosophy is still valid in NATO nations and with that a correspondingly different leadership style is practised. This is not in line with the tenets behind this form of $\mathrm{C} 2$, resulting in mission command at the lowest tactical level in a multinational environment being impeded. Furthermore, politics and language hamper C2 interoperability at this tactical level.

The research also identified opportunities to improve the application of mission command within NATO and combined units. Modern technology is a good supporter and promoter, but can be an additional issue. The 'human aspect' of $\mathrm{C} 2$ was and will not be supplanted by technology. Mission command with its described tenets is the C2 philosophy which provides the tools for military leaders to take appropriate decisions. If it is effectively and commonly institutionalised and applied within NATO and its members, it has tremendous potential against rapidly emerging and diverse security threats and challenges, both current 
and in the future. However, the research conducted and issues identified in this study clearly indicate that a common and standardised application is not the reality at present.

Finally, one should heed General Capewell (2018) warning that, "[i]t is fine to fight the next years' war with the last years' forces. But it is inexcusable to fight the next years' wars and conflicts with the last years' concept."

Please note that the views expressed in this article are those of the author alone and should not be taken to represent the views of the Bundeswehr, the Irish Command and Staff School or any other group or organisation.

\section{BIBLIOGRAPHY}

Alberts, D. S., \& Hayes, R. (1995). Command Arrangements for Peace Operations. Washington D.C.: National Defence University Press Publication.

Alwyn-Foster, B. N. (2005). Changing the Army for Counterinsurgency Operations. Military Review, 84 (6), pp. 2-15.

Barth, T. (1994). Auftragstaktik - A Leadership Philosophy For The Information Age. (School of Advanced Studies, Ed.) Fort Leavenworth, Kansas: US Army Command and General Staff College.

Bateman, R. (1996). Force XXI and the Death of Auftragstaktik. ARMOR, January- February, pp. 13-15.

Ben-Shalom, U., \& Shamir, E. (2011). Mission Command Between Theory and Practice: The Case of the IDF. Defence \& Security Analysis, 27 (2), pp. 101-117.

Bially, T. (2005). Lifting the Fog of War. DAPRATech, August, pp. 87-90. Biehl, H. (2012). Military Cooperation in Multinational Missions. In H. Haas, F. Kernic, \& A. Plaschke (Eds.), Leadership in Challenging Situations (New Edition). Frankfurt/ Main: Peter Lang GmbH, pp. 109-137.

Blad, T., \& Potts, D. (2003). Beyond Interoperability: Part 1. The Occasional, 45, pp. 139-150.

Britt, A. S. (2003). The Wars of Napoleon. (Department of History, United States Military Academy Westpoint, Ed.) Garden City Park, NY: SquareOne Publishers Inc.

Bühlmann, C., \& Braun, P. (2010). Auftragstaktik in Vergangenheit, Gegenwart und Zukunft. Military Power Revue der Schweizer Armee, 1, pp. 50-63.

BMVg - Bundesministerium der Verteidigung. (2016). Weißbuch. Berlin: Bundesministerium der Verteidung.

BPB - Bundeszentrale für politische Bildung. Retrieved from Politik, Hintergrund aktuell (27 February 2017): http://www.bpb.de/politik/hintergrund-aktuell/243279/nato-einsatz [accessed 22 September 2017].

Bungay, S. (2003). The Road to Mission Command: The Genesis of a Command Philosophy. from

blindscommercial: http://www.blindscommercial.com/files\%20from\%20irun\%20DO\%20NOT\%20 DELETE/blindsco\%20from\%20irun/public_html/userfiles/file/Bungay\%20Miss ion\%20Command\%20for\%20BAR.pdf [accessed 21 September 2017]. 
Butler, C.-H. v. (2008). Führen mit Auftrag: Herausforderungen und Chancen. Zeitschrift für Innere Führung, 52 (4), pp. 13-19.

Butler, C.-H. v. (2009). Auftragstaktik - wir müssen sie annehmen und gestalten. Der Panzerspähtrupp, October (46), pp. 6-7.

Capewell, D. (2018). Command, Leadership \& Human Resources Management, Module bode: Operations in a Volatile \& Hybrid Future. 01 February 2018, C\&S School, Curragh Camp, unpublished lecture.

Caton, C. (2009). Towards Creating Operational Commanders in the Canadian Forces: Is Auftragstaktik the model? Toronto: Canadian Forces College. Retrieved from http://www.cfc.forces.gc.ca/papers/amsc/amsc4/caton.pdf [accessed 18 November 2017].

Ciocan, F. (2011). Perspectives on Interoperability Integration within NATO Defence Planning Process. Journal of Defense Resources Management, 2 (2), pp. 53-66.

Clausewitz, C. v. (2003). Vom Kriege (4. Auflage ed.). Berlin-München: Ullstein Heine List Gmbh \& Co. KG.

Cohen, E. A. (2004). Change and Transformation in Military Affairs. Journal of Strategic Studies, 27 (3), pp. 395-407.

Creswell, J. (2003). Research Design: Qualitative, Quantitative and Mixed Methods Approaches (2 ed.). Thousand Oaks, CA: SAGE Publications.

Davis, P. K. (2001). Effects-Based Operations - A Grand Challenge for the Analytical Community. Santa Monica, Arlington, Pittsburgh: RAND Corporation. Retrieved from https://www.rand.org/content/dam/rand/pubs/monograph_reports/2006/MR1477.p df [accessed 09 March 2018].

Decamp, L. (2014). NATO Interoperability: Connecting Forces Today and Tomorrow. Geospatial Today, pp. 1-4. [accessed 19 November 2017].

Dempsey, R., \& Chavous, J. M. (2013). Commander's Intent and Concept of Operations. Military Review, November-December, pp. 58-66.

Department of National Defence. (2009). CFJP 01 - Canadian Military Doctrine. Ottawa: Canadian Forces Experimentation Centre.

Department of the Army, H. (1997). Field Manual No. 101-5; Staff Organizations and Operations. Washington D.C.: Department of the Army. Retrieved from https://www.globalsecurity.org/military/library/policy/army/fm/101-5/f540.pdf [accessed 09 March 2018].

Department of the Army, H. (2003). Field Manual No. 6-0: Mission Command: Command and Control of Army Forces. Washington D.C.: Department of the Army.

Department of the Army, H. (2009). Field Manual No. 3-55.93; Long-Range Surveillance Unit Operations. Washington D.C.: Department of Army. Retrieved from https://archive.org/details/FM3-55x93 [accessed 09 March 2018].

Department of the Army, H. (2012). Army Doctrine Reference Publication No. 6-0: Mission Command. Washington D.C.: Department of the Army. 
Dunivan, J. (2003). C2 on the digitized battlefield: surrendering the initiative? Military Review, September-October (83), pp. 2-10.

Elron, E., Shamir, B., \& Ben-Ari, E. (1999). Why Don't They Fight Each Other? Cultural Diversity and Operational Unity in Multinational Forces. Armed Forces and Society, 26 (1), pp. 73 98.

European Union. (2017). External Action. Retrieved from https://eeas.europa.eu/headquarters/headquarters-homepage_en (16 November 2017) [accessed 01 December 2017].

Felde, H., \& May, P. (1981). Auftragstaktik und Befehlstaktik? Lagebedingte Anwendung des jeweiligen Führungsprinzips erforderlich. Truppenpraxis Wehrausbildung, February, pp. 91-94.

Freudenberg, D. (2008). Auftragstaktik versteht jeder: Multinationalität und Innere Führung. Zeitschrift für Innere Führung, 52 (3), pp. 43-45.

Freudenberg, D. (2009). Das britische Führungsverständnis unter besonderer Berücksichtigung deutschen Führungsdenkens. Österreichische militärische Zeitschrift, 47 (1), pp. 62-70.

Freudenberg, D. (2012). Rule of Engagement. Möglichkeiten und Grenzen eines militärischen Führungsinstruments? Zu den Wechselwirkungen von Recht und Strategie im deutschen Führungsdenken. In M. Hofbauer (Ed.), Kriegsbrauch und berufliches Selbstverständnis von Soldaten. Freiburg im Breisgau: Militärgeschichtliches Forschungsamt, pp. 19-44.

Freudenberg, D., \& Sayin, D. (2008). Multinationalität: Mit Händen und Füßen. Y - Magazin der Bundeswehr: Special August: Innere Führung - Immer im Einsatz, pp. 100-103.

Freundenberg, D. (2005). Militärische Führungsphilosophien und Führungskonzeptionen ausgewählter NATO- und WEU-Staaten im Vergleich. (P. D. Steinkamm, Ed.) BadenBaden: Nomos.

Guthrie, T. (2012). Mission Command: Do We Have the Stomach For What is Really Required? Army, June, pp. 26-28.

Häberli, T. (2010). Befehlsgebung der US Army - Auftrags- oder Befehlstaktik? Allgemeine schweizerische Militärzeitschrift, 176 (7), pp. 28-29.

Hughes, D. (1993). Moltke on the Art of War: Selected Writings (New Edition ed.). (D. Hughes, Ed.) New York: Ballantine Books.

Irish Defence Forces. (2016). DFDM - J1: Defence Forces Capstone Doctrine. Dublin: Irish Defence Forces.

Jablonsky, D. (1994). US Military Doctrine and the Revolution in Military Affairs. Parameters, Autumn, pp. 18-36.

Jernigan, M. (2016). Combat Initiative or Combating Initiative? The links between valor, initiative, and what leaders can do about it. Marine Corps Gazette: professional journal of U.S. Marines, 100 (8), pp. 32-36. 
Joint Chiefs of Staff. (2012). Mission Command White Paper. Washington D.C.: Department of Defence.

Joint Chiefs of Staff. (2014). Joint Publication 3-09: Joint Fire Support. Washington D.C.: Department of Defence.

Keithly, D., \& Ferris, S. (1999). Auftragstaktik, or Directive Control, in Joint and Combined Operations. Parameters, Autumn, pp. 118-133.

King, A. C. (2017). Mission Command 2.0: From an Individualist to a Collectivist Model. Parameters, 47 (1), pp. 7-19.

Klos, D. (2006). Vernetzte Operationsführung des Heeres im internationalen Kontext. Europäische Sicherheit: Politik, Streitkräfte, Wirtschaft, Technik, 55 (5), pp. 54-61.

Kober, A. (2011). What Happened to Israeli Military Thought. Journal of Strategic Studies, 34 (5), pp. 707-732.

Kommando Heer, (2017). C1-160/0-1001: Truppenführung. Strausberg: Kommando Heer.

Kommando Heer, (2017). C1-160/0-1004: Truppenführung - Deutscher Führungsprozess der Landstreitkräfte. Strausberg: Kommando Heer.

Kommando Heer, (2015). C1-100/0-1000-1: Truppenführung. Strausberg: Kommando Heer.

Land Warfare Development Centre. (2017). Army Doctrine Publication: Land Operations. Warminster: Headquarters Field Army.

Lefever, P. (2003). Beyond Interoperability: Part 2. (D. Potts, Ed.) The Occasional, February (45), pp. 151-166.

Leistenschneider, S. (2009). Auftragstaktik im preussisch-deutschen Heer 1871-1914. Der Panzerspähtrupp, October (46), pp. 24-27.

Leonhard, R. (1991). The Art of Maneuver: Maneuver-Warfare Theory and the AirLand Battle. New York: Ballantine Books.

Leonhard, R. (1993). Manoeuvre Warfare and the United States Army. In R. Hooker, Manoeuvre Warfare: An Anthology. New York: NY Press, pp. 42-56.

Macey, P. J. (1998). The British Army and the Failure of Mission Command. The British Army Review, 118, pp. 87-90.

McCann, C., \& Pigeau, R. (1999). Clarifying the Concepts of Control and of Command. Toronto: Defence and Civil Institute of Environmental Medicine. Retrieved from https://s3.amazonaws.com/academia.edu.documents/43477770/019mccan.pdf?A WSAccessKeyld=AKIAIWOWYYGZ2Y53UL3A\&Expires=1510010171\&Sign

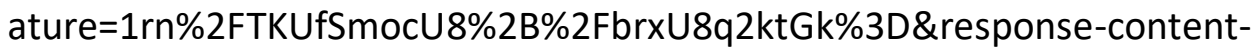
disposition=inline\%3B\%20filename\%3DClarifying_the_Concepts_of_Cont [accessed 05 November 2017].

McChrystal, S., Collins, T., Silverman, D., \& Fussell, C. (2015). Team of Teams: New Rules of Engagement for a Complex World. New York: Portfolio / Penguin.

McGinn, A. (2018). Thesis. Module bode: Data Gathering Techniques and Research Interviewing, 11 January 2018, C\&S School, Curragh Camp, unpublished lecture. 
Millotat, C. (2002). Auftragstaktik, das oberste Führungsprinzip im Heer der Bundeswehr: ihre Entwicklung und Darstellung in deutschen militärischen Führungsgrundlagen. (Führungsakademie der Bundeswehr, Ed.) Reihe "Beiträge zur Weiterentwicklung der Lehre", 1, pp. 1-32.

Ministerie van Defensie. (2012). Joint Doctrine Publications 5 - Command and Control. Amsterdam: Ministry of Defence of the Netherlands.

Nelson, J. T. (1987). Auftragstaktik: A Case for Decentralized Battle. Parameters, September, pp. 21-34.

North Atlantic Treaty Organization. (2006). Backgrounder: Interoperability for joint operations. Brussels: Public Diplomacy Division.

North Atlantic Treaty Organization. (2013). Allied Administrative Publication 06: NATO Glossary of Terms and Definitions. Brussels: NATO Standardization Office (NSO).

North Atlantic Treaty Organization. (2016). Allied Joint Publication 3.2: Allied Joint Doctrine for Land Operations (A, Version 1 ed.). Brussels: NATO Standardization Office (NSO).

North Atlantic Treaty Organization. (2016). What is NATO? (16 July 2016). Retrieved from https://www.nato.int/nato-welcome/index.html [accessed 21 April 2018].

North Atlantic Treaty Organization. (2017). NATO's Enhanced Forward Presence, Factsheet. Brussels: Public Diplomacy Division.

North Atlantic Treaty Organization. (2017). Partnership Interoperability Initiative - PII (07 June 2017). Retrieved from https://www.nato.int/cps/ic/natohq/topics_132726.htm [accessed 01 December 2017].

North Atlantic Treaty Organization. (2017). Topics. Retrieved from Interoperability: Connecting NATO Forces (23 January 2017): http://www.nato.int/cps/en/natohq/topics_84112.htm [accessed 23 September 2017].

Oetting, D. W. (1993). Auftragstaktik, Geschichte und Gegenwart einer Führungskonzeption. Frankfurt am Main/Bonn: Report Verlag GmbH.

Oliviero, C. (2001). Auftragstaktik and Disorder in Battle: Learning to "See the Battlefield" Differently. The Army Doctrine and Training Bulletin, 4 (2), pp. 57-59.

Patton, G. S. (2017). George S. Patton Quotes. Retrieved from BrainyQuote.com: https://www.brainyquote.com/quotes/george_s_patton_106027 [accessed 16 December 2017].

Pfrengle, F. X. (2009). Führen mit Auftrag braucht Ausbildung und Erziehung im Nachwuchs. Der Panzerspähtrupp, October (46), pp. 30-31.

Pryer, D. A. (2013). Growing Leaders Who Practice Mission Command and Win the Peace. Military Review, November-December, pp. 31-41.

Rubenstein, R. A., Keller, D. M., \& Scherger, M. E. (2008). Culture and Interoperability in Integrated Missions. International Peacekeeping, 15 (4), pp. 540-555. 
Ruffa, C. (2012). What kind of Military Leadership for what Kind of Operation? Assessing 'Mission Command' in Peace Operations and Counterinsurgencies. In F. Harald Haas (Ed.), Leadership in Challenging Situations (New Edition). Frankfurt/ Main: Peter Lang $\mathrm{GmbH}, \mathrm{pp} .183-194$.

Ryan, A. B. (2015). Methodology: Collecting Data. In T. Walsh, \& A. Ryan (Eds.), Writing your thesis: A guide for postgraduate students. Maynooth, Co. Kildare: MACE Press, pp. 117138.

Ryan, A. B. (2015). Post-Positivism Aprroaches to the Research. In T. Walsh, \& A. Ryan (Eds.), Writing your thesis: a guide for the postgraduate students. Maynooth, Co. Kildare: MACE Press, pp. 23-38.

Schmidtchen, D. (2001). Developing Creativity and Innovation through the Practise of Mission Command. Australian Defence Forces Journal, January-February (146), pp. 11-17.

Shamir, E. (2010). The Long and Winding Road: The US Army Managerial Approach to Command and the Adoption of Mission Command (Auftragstaktik). The Journal of Strategic Studies, 33 (5), pp. 645-672.

Shamir, E. (2011). Transforming Command: The Pursuit of Mission Command in the U.S., British, and Israeli Armies (e-book ed.). Stanford, California: Standford University Press.

Spacie, K. (2000). Leadership and Command. In G. Harries-Jenkins, Leadership for Change, pp. 85-93. Alexandria, VA: United States Army Research Institute for the Behavioral and Social Sciences.

Speller, D. I. (2017). Defence \& Security Studies, Module bode: International Relations - Classic Strategy Theories, 21 September 2017, C\&S School, Curragh Camp, unpublished lecture.

Stewart, K. (2009). Mission Command: Problem Bounding or Problem Solving. Canadian Military Journal, 9 (4), pp. 50-59.

Stewart, K. (2006). Mission Command: Elasticity, Equilibrium, Culture, and Intent. Toronto: Defence R\&D Canada.

Stewart, K., Cremin, D., Mills, M., \& Phipps, D. (2004). Non-technical interoperability: The collapse of command leadership in multinational operations. Farnborough- Sunbridge: QinetiQ Ltd.

Storr, J. (2003). A Command Philosophy for the Information Age: the Continuing Relevance of Mission Command. (D. Potts, Ed.) The Occasional, February (45), pp. 77-94.

Thornal, M. (2017). Trust in Mission Command - The Critical Component? Maynooth: Maynooth University, unpublished thesis.

Van Bezooijen, B., \& Kramer, E.-H. (2015). Mission Command in the Information Age: A Normal Accidents Perspective on Networked Military Operations. Journal of Strategic Studies, 38 (4), pp. 445-466.

van Crefeld, M. (2002). Command in War (Tenth Printing ed.). Cambridge, Massachusetts, and London, England: Harvard University Press.

Vandergriff, D. (2013). Misinterpretation and Confusion: What is Mission Command and Can the U.S. Army Make it Work? The Land Warfare Papers, February (94), pp. 1-22. 
Vogelaar, A. L., \& Kramer, E.-H. (2004). Mission Command in Dutch Peace Support Missions. Armed Forces \& Society, Spring, pp. 409-431.

Wallander, C. A. (2000). Institutional Assets and Adaptability: NATO After the Cold War. International Organizations, 54 (4), pp. 705-735.

Watters, B. (2013). Mission Command: a Reality Check. Cranfield: Cranfield University. Retrieved from https://www.raf.mod.uk/.../225D11C3_5056_A318_A8AF63C0..D16C7670.doc [accessed 01 February 2018].

Whittaker, J. (2009). Mission Command: The Peace Panacea? A Study of the Potential Impact of Mission Command Philosophy on the Irish Defence Forces in Peace Support Operations. Maynooth: Maynooth University, unpublished thesis.

Widder, W. (2002). Auftragstaktik and Innere Führung: Trademarks of German Leadership. Military Review: the professional journal of the US Army, September-October, pp. 3-9.

Williams, C. (2007). Research Methods. Journal of Business and Economic Research, 5 (3), pp. 65-71.

Willmann, H. (1998). Leadership: der militärische Führer im Einsatz - Forderungen für Erziehung und Ausbildung. Bonn: Fachinformationszentrum der Bundeswehr.

Wilson, P. H. (2008). Defining Military Culture. The Journal of Military History, 72 (1), pp. 1-41. 